\title{
Evaluation of cytotoxic profile of hydroalcoholic extract of fruit rinds of Garcinia pedunculata on human embryonic kidney and breast carcinoma cells
}

\author{
Sukrant Sharma ${ }^{1}$, Ravi Mundugaru ${ }^{2}$, Pradeepa H. Dakappa ${ }^{3 *}$, Pundalik R. Naik ${ }^{4}$
}

\begin{abstract}
${ }^{1}$ Department of Shalya Tantra, Jammu Institute of Ayurveda and Research, Jammu, India
${ }^{2}$ Department of Pharmacology, DM Wayanad Institute of Medical Sciences, Wayanad, Kerala, India

${ }^{3}$ Department of Pharmacology, MVJ Medical College and Research Hospital, Dandupalya, Hoskote, Karnataka, India

${ }^{4}$ Department of Biochemistry, Kodagu Institute of Medical Sciences, Madikeri, Karnataka, India
\end{abstract}

Received: 28 December 2019

Accepted: 14 January 2020

*Correspondence:

Dr. Pradeepa H. Dakappa,

Email: pradeep.1ikon@gmail.com

Copyright: (C) the author(s), publisher and licensee Medip Academy. This is an open-access article distributed under the terms of the Creative Commons Attribution Non-Commercial License, which permits unrestricted non-commercial use, distribution, and reproduction in any medium, provided the original work is properly cited.

\begin{abstract}
Background: The fruit rinds of Garcinia pedunculata has potential medicinal properties and used in many chronic ailments. It has been demonstrated that cytoprotective effects in various experimental research works. But its cytotoxic effect has not been evaluated. The present study was aimed to screen its relative cytotoxic effect on normal and cancer cell lines.

Methods: In the present study, the cytotoxic effect of hydro alcoholic extract of Garcinia pedunculata was evaluated on normal human embryonic kidney (HEK-293) and M.D. Anderson metastatic breast cancer cell lines (MDA-MB 231) using 3-(4, 5-dimethylthiazol-2-yl)-2, 5-diphenyltetrazolium bromide (MTT) assay.

Results: Higher dose level of hydro alcoholic extract of Garcinia pedunculata (HAGP) (500 $\mu \mathrm{g} / \mathrm{ml})$ has shown considerable increase (112.503) in the percentage viability of HEK-29 whereas; there is a remarkable decrease in the viable cell population (77.490) in MDA-MB 231.

Conclusions: Based on the observed results we could conclude that HAGP has potential cytotoxic effect on the cancer cell line without altering the normal cell growth and proliferation. Thus it has potential to develop as a safer chemotherapeutic agent. Further detailed exploration is required to confirm its therapeutic efficacy in different cancer cell lines.
\end{abstract}

Keywords: Human embryonic kidney cells, Metastatic breast cancer, Cisplatin, Nephroprotective, Cytotoxic

\section{INTRODUCTION}

The dried fruit rinds of Garcinia pedunculata (GP) have many important medicinal properties and have been used in different disease conditions. G. pedunculata Roxb. Fam. Clusiaceae trees are commonly seen in north eastern states of India, Bangladesh and Andaman Nicobar islands. The tribal communities of these regions were regularly used the dried form of fruit rinds in their diet and found medicinal values. The folklore use claims that it has good therapeutic effect in fever, cough, bronchial asthma, rheumatoid arthritis, obesity, atherosclerosis, cardiovascular disease, infectious and inflammatory diseases. ${ }^{1}$ It has been reported to possess the following vital phytochemical compositions such as garcinol, pedunculol, cambogin and (-)-hydroxy citric acid. ${ }^{2,3}$ The hydro alcoholic extract of G. pedunculata (HAGP) has been reported to show cardio protective activities against isoprenaline induced myocardial infarction in rats. ${ }^{4}$ The HAGP has been found that the hepatoprotective activity 
against paracetamol induced hepatotoxicity. ${ }^{5}$ Previous pharmacological studies have stated that it has potent antimicrobial and anti-inflammatory properties with potent antioxidant and free radicle scavenging activities. $^{6,8}$ It has shown to have a protective activity against cisplatin induced nephrotoxicity in Wistar albino rats and protected kidney tissues from cisplatin induced severe oxidative stress. 9 The hexane and chloroform fraction of GP has shown antimutagenecity properties. ${ }^{3}$

The use of synthetic cancer chemotherapy is associated with high degree of adverse effects and overweighs its potential therapeutic benefits. Most of the chemotherapeutic agents kill both normal and tumorous cells and hence posed with numerous toxicity profiles. In this regard many phytomedicines derived from herbal sources were screened for their significant cytotoxic effects. It has been reported that the plant derived alkaloids such as vincristine, vinblastine and epipodo-phyolotixines possess good cytotoxic effects in various solid tumors. ${ }^{11}$ Meanwhile, phytomedicine possess potent anti-oxidant and cytoprotective activity in normal cells as well.The dried fruit rinds of GP have been reported to show its antioxidant, cytoprotective activity. ${ }^{5,6}$ However, there are no studies reported on cytotoxic effect of $G$. pedunculata. Thus, the aim of the present study was to screen the effect of hydro alcoholic extract of fruit rinds of G. pedunculata on normal (human embryonic kidney cells) and metastatic breast cancer cell lines.

\section{METHODS}

3-(4, 5-dimethylthiazol-2-yl)-2, 5-diphenyltetrazolium bromide (MTT) -Sigma Aldrich, dimethyl sulfoxide (DMSO), phosphate buffer saline (PBS), 96 well plate, human embryonic kidney (HEK-293), minimum essential medium eagle, fetal bovine serum, M.D. Anderson metastatic breast cancer cell lines (MDA-MB), and Leibovitz's medium. All chemicals and reagents used were of analytical grade.

\section{Plant material}

The fruit rinds of $G$. pedunculata were collected from Assam during the month of April 2016. It was authenticated in Pharmacognosy laboratory at SDM Centre for Research in Ayurveda and Allied Sciences, Udupi and the voucher specimen (No. 13100501) has been deposited for future reference.

\section{Extract preparation}

The fruit rinds were shade dried and powdered at SDM Pharmacy Udupi. The powder obtained from a single batch was used throughout the study. Fruit powder of $G$. pedunculata weighing $100 \mathrm{~g}$ was soaked in 0.4 litre of cold distilled water for 24 hour was filtered and concentrated by evaporation. The concentrated extract was used for cell viability studies.

\section{Cytotoxicity study}

In the present study two cell lines, HEK-293 and MDAMB-231 were opted. The confluent cell line was taken in flask and trypsinized the cells. The cells were washed twice with PBS and centrifuged it. The pellet was suspended in MEM (E) and Leibovitz medium with $10 \%$ foetal bovine serum respectively. The cells were counted using haemocytometer. Cells around 10,000 cells/well were plated to 96 well plate and incubated at $37^{\circ} \mathrm{C}$ in $\mathrm{CO}_{2}$ incubator for $24 \mathrm{hrs}$. After 24 hours of incubation old medium was discarded from 96 well plates. Dissolved the different concentrations of drug in suitable serum free medium and add to the different test groups. The cells were incubated for 24 hours at $37^{\circ} \mathrm{C}$ in $\mathrm{CO}_{2}$ incubator. After completion of incubation time added $20 \mu \mathrm{L}$ of MTT dye $(5 \mathrm{mg} / \mathrm{ml}$ in PBS) to all wells. The plates were covered with aluminium foil and incubate in $\mathrm{CO}_{2}$ incubator for four hours. After four hours added $100 \mu \mathrm{l}$ of DMSO to all the wells and mixed it by careful shaking. The absorbance was recorded using multiwell plate reader record at $540 \mathrm{~nm}$ (or $540 \mathrm{~nm}$ with reference to 630 $\mathrm{nm}$ ) and the percentage viable cells were calculated using following formula $\%$ of viable cells $=[$ (Test sampleblank) / (Control-blank)] $\times 100 .{ }^{10}$

\section{RESULTS}

\section{Effect of HAGP on HEK-293}

HAGP at graded dose has shown increase in the percentage viability of MDA-MB 231 cells. HAGP at 10 , 20, 50,100, 200, 500 and $1000 \mu \mathrm{g} / \mathrm{ml}$ concentrations has shown the \% live cells of $80.768,80.770,83.222,83.082$, 95.203, 108.498 and 112.503 respectively. Control group has shown $100 \%$ live cells whereas; the Cisplatin at 500 $\mu \mathrm{g} / \mathrm{ml}$ has shown $32.99 \%$ live cells (Figure 1).

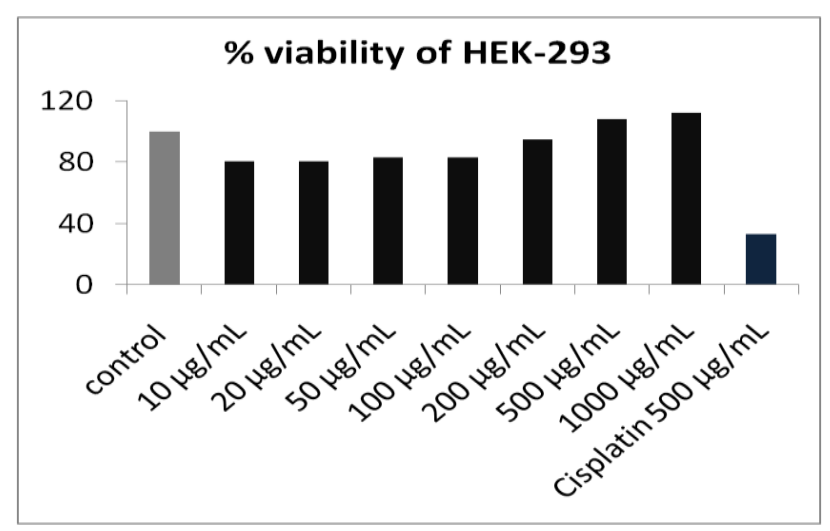

Figure 1: Effect of HAGP on HEK-293.

\section{Effect of HAGP on MDA-MB 231}

HAGP at graded dose has shown decrease in the percentage viability of MDA-MB 231 cells. HAGP at 10, 20, 50, 100, 200, 500 and $1000 \mu \mathrm{g} / \mathrm{ml}$ concentrations has shown the\% live cells of $91.067,85.071,82.256,82.875$, 
$81.309,79.223$ and 77.490 respectively. Control group has shown $100 \%$ live cells whereas; the Cisplatin at 500 $\mu \mathrm{g} / \mathrm{ml}$ has shown $32.066 \%$ live cells (Figure 2).

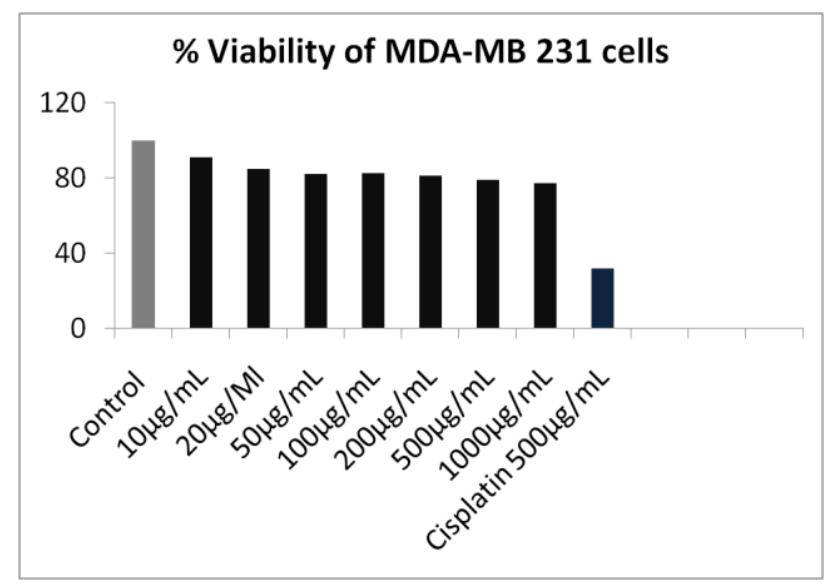

Figure 2: Effect of HAGP on MDA-MB 231.

\section{DISCUSSION}

The present study was conducted to evaluate the cytotoxic potentials of hydro alcoholic extract of $G$. pedunculata (HAGP) at various concentrations on both normal cell line such as human embryonic kidney cells (HEK-293) and metastatic breast carcinoma (MDA-MB 231) cells using direct counting of percentage viability of cells.

In the present study, we observe that there is a considerable increase in the percentage viable of HEK293 cells when incubated at higher concentration of HAGP as compared to the lower doses. The minimum dose of the test drug selected for the present study was $10 \mu \mathrm{g} / \mathrm{mL}$ and we observed 80.768 percentage of viable cells. However, at higher dose such as $500 \mu \mathrm{g} / \mathrm{ml}$ and $1000 \mu \mathrm{g} / \mathrm{ml}$, we found 108.498 and 112.503 percentage viability respectively. The increase in percentage of viable HEK-293 cells was considerably higher when compared to the normal control group. These preliminary observations indicate that the test drug HAGP has a potential to stimulate normal cell proliferation. The exact mechanism of action and the important phyto-constituents responsible for increase in percentage of viable HEK-293 cells in the present finding could confirm only by further detailed investigations.

The effect of HAGP on Metastasis breast cancer cell line 231 has shown a considerable decrease in the percentage viability at various dose levels of HAGP. We observed 91.067 percentage viability at lowest concentration (10 $\mu \mathrm{g} / \mathrm{ml}$ ) and a graded decrease in the percentage viability was observed in the following order 85.071, 82.256, $82.875,81.309,79.223$ and 77.490 at 20, 50, 100, 200, 500 and $1000 \mu \mathrm{g} / \mathrm{ml}$. The result indicates that there is a significant decrease in the percentage viability of metastatic breast cancer cell line, when these were incubated with various dose levels of HAGP. The earlier study reported that G. Pedunculata has shown potent antioxidant and free radical scavenging activities. ${ }^{5}$ In addition, it has potent role in the protection of liver, kidney and cardiac tissues against various toxicants. ${ }^{9}$ The hexane fraction of $G$. pedunculata fruit rinds possess anti mutagenic properties. ${ }^{3}$ The phytochemicals such as garcinol, (-) - hydroxy citric acid and phenolic compounds such as pedunulol were responsible for its various pharmacological activities. ${ }^{2}$ The present preliminary study result indicates that HAGP has potential to kill or inhibit the rate of proliferation of cancer cells at various levels. However, there is a need of detailed exploration of present findings like the important phyto-constituent responsible for cytotoxic activity and dose selection.

\section{CONCLUSION}

The present study concludes that HAGP has a potent cytotoxic activity in the cancerous cell lines and has promising proliferator effect on normal cell line. Thus it can be a better alternative chemotherapeutic agent if it was refined and explored the specific phytomedicine responsible for cytotoxic effects on abnormal cell lines.

\section{ACKNOWLEDGEMENTS}

The authors are highly grateful to Chairman of DM WIMS, Wayanad, India for his constant motivation to carry out this research work and Dr. Antony Sylvan D' Souza, Dean, DM WIMS, Wayanad, Kerala, India for his constant support.

\section{Funding: No funding sources \\ Conflict of interest: None declared \\ Ethical approval: Not required}

\section{REFERENCES}

1. Kagyung R, Gajurel PR, Rethy P. Singh B. Ethnomedicinal plants used for gastrointestinal diseases by Aditribes of Dehang-Debang Biosphere Reserve in Arunachal Pradesh. Indian J Tradit Know. 2010;9:496-501.

2. Sahu A, Das B, Chatterjee A. Polyisoprenylated benzophenones from Garcinia pedunculata. Phytochemistry. 1989;28(4):1233-5.

3. Jayaprakasha GK, Jena BS, Sakariah KK. Improved liquid chromatographic method for determination of organic acids in leaves, pulp, fruits, and rinds of Garcinia. J AOAC Int. 2003;86(5):1063-8.

4. Ravi M, Senthilkumar S, Padmaja U, Sudhakara B. Cardio protective activity of fruits extract of Garcinia pedunculata. Bangladesh J Pharmacol. 2016;11:5-9.

5. Ravi M, Madhan C, Ravishankar B. Hepatoprotective activity of fruits extract of Garcinia pedunculata. Bangladesh J Pharmacol. 2014;9:4-8.

6. Negi PS, Jayaprakasha GK, Jena BS. Antibacterial activity of the extracts from the fruit rinds of Garcinia cowa and Garcinia pedunculataagainst food borne pathogens and spoilage bacteria. LWT-Food Sci Technol. 2008;41(10):1857-61. 
7. Jayaprakasha GK, Negi PS, Jena BS. Antioxidative and antimutagenic activities of the extracts from the rinds of Garcinia pedunculata. Innovative Food Science Emerging Technologies. 2006;7(3):246-50.

8. Mundugaru R, Joy F, Shrinidhi R, Das L, Sudhakara RB. Anti-inflammatory activity of aqueous extract of fruits of Garcinia pedunculatain experimental animals. Am J Pharma Tech Res. 2014;4(3).

9. Ravi M, Sivanesan S, Febin J, Sunil Kumar KN, Lekshmi R, Alfarhan AH, et al. Quality Standardization and Nephroprotective Effect of Garcinia Pedunculata roxb. Fruit rind. IJPER. 2017:51:136-44.

10. Mosmann T. Rapid colorimetric assay for cellular growth and survival:application to proliferation and cytotoxicity assays. J Immunol Methods.1983;65(12):55-63.

11. Desai AG, Qazi GN, Ganju RK, El-Tamer M, Singh J, Saxena AK, et al. Medicinal plants and cancer chemoprevention. Curr Drug Metab. 2008;9(7):58191.

Cite this article as: Sharma S, Mundugaru R, Dakappa PH, Naik PR. Evaluation of cytotoxic profile of hydroalcoholic extracts of fruit rinds of Garcinia pedunculata on human embryonic kidney and breast carcinoma cells. Int J Basic Clin Pharmacol 2020;9:259-62. 